\title{
New Records of Four Doridoidean Nudibranchs from Korea
}

\author{
Daewui Jung ${ }^{1}$, Jongrak Lee ${ }^{2}$, Chang-Bae Kim,* \\ 'Department of Life Science, Sangmyung University, Seoul 110-743, Korea \\ ${ }^{2}$ Marine Biodiversity Research Institute, INTHESEA KOREA Inc., Jeju 697-110, Korea
}

\begin{abstract}
Specimens of nudibranchs have been surveyed by scuba diving from 9 localities along the Korean coast. By examination of morphological characteristics, four species in the superfamily Doridoidea which are new to Korea were identified, and re-described: Thorunna florens (Baba, 1949), Diaulula sandiegensis (Cooper, 1863), Jorunna parva (Baba, 1938), and Doris odhneri (MacFarland, 1966). In addition, radulae of three species were observed and photographed by using scanning electron microscopy. As a result of the study, 16 species of doridoidean nudibranch are now known from Korean waters.
\end{abstract}

Keywords: Nudibranchia, Doridoidea, taxonomy, Thorunna florens, Diaulula sandiegensis, Jorunna parva, Doris odhneri, Korea

\section{INTRODUCTION}

The Nudibranchia is a large member of marine mollusks (Gosliner et al., 2008). Species of the superfamily Doridoidea in the nudibranchs are characterized by wide mantle skirt (Debelius and Kuiter, 2007). There were only 12 species recorded from Doridoidea in Korean waters (Choe, 1992; Lee, 1993; Choe and Lee, 1994; Lee and Min, 2002; Choi, 2003): Aldisa cooperi Robilliard and Baba, 1972, Cadlina japonica Baba, 1937 in the Family Cadlinidae; Ceratosoma trilobatum (J.E. Gray, 1827), Chromodoris orientalis Rudman, 1983, Chromodoris quadricolor (Rüppell and Leuckart, 1828), Glossodoris misakinosibogae Baba, 1988, Goniobranchus aureopurpureus (Collingwood, 1881), Goniobranchus tinctorius (Rüppell and Leuckart, 1828), Hypselodoris festiva (A. Adams, 1861), Noumea purpurea Baba, 1949 in the Family Chromodorididae; Homoiodoris japonica Bergh, 1882 in the Family Dorididae; Platydoris ellioti (Alder and Hancock, 1864) in the Family Discodorididae. In this study, 4 species of Korean doridoidean nudibranchs are re-described as new records for Korean fauna: Thorunna florens (Baba, 1949), Diaulula sandiegensis (Cooper, 1863), Jorunna parva (Baba, 1938), and Doris odhneri (MacFarland, 1966). Photographs of the external morphology and radula teeth are also provided.
Specimens were collected by scuba diving in the Korean coast. Materials were fixed in $10 \%$ neutral buffered formalin or $97 \%$ ethanol after treatment with a $8 \% \mathrm{MgCl}_{2}$ solution. The materials were observed and dissected with a stereoscopic microscope (Olympus SZ-61 with FuzhouTucsen TCA-3, Tokyo, Japan). Body lengths of most specimens examined were measured from the front of the rhinophores to the tip of the metapodium. For examining radulae, the buccal mass was dissolved in $10 \%$ potassium hydroxide solution until the radulae were isolated. The radulae were dried, mounted on stubs, coated with gold, and observed by a scanning electron microscope (HITACHI S-4300, Tokyo, Japan) with accelerating voltage of $10 \mathrm{kV}$. The specimens examined in this study were deposited in the National Institute of Biological Resources (NIBR), Incheon, Korea and Sangmyung University, Seoul, Korea. NIBR specimen numbers are indicated in parentheses beside the specimens.

\section{SYSTEMATIC ACCOUNTS}

Phylum Mollusca Linnaeus, 1758

Class Gastropoda Cuvier, 1795

Order Nudibranchia Cuvier, 1817

Superfamily Doridoidea Rafinesque, 1815
(C) This is an Open Access article distributed under the terms of the Creative Commons Attribution Non-Commercial License (http://creativecommons.org/ licenses/by-nc/3.0/) which permits unrestricted non-commercial use, distribution, and reproduction in any medium, provided the original work is properly cited.

pISSN 2234-6953 eISSN 2234-8190
*To whom correspondence should be addressed

Tel: 82-2-2287-5288, Fax: 82-2-2287-0070

E-mail: evodevo@smu.ac.kr 
Diagnosis. Mostly oval. Head distinct form their body. Gills retractile into a gill pocket. Mantle skirt wide (Debelius and Kuiter, 2007).

Family Chromodorididae Bergh, 1891

Genus Thorunna Bergh, 1878

\section{Thorunna florens (Baba, 1949) (Fig. 1)}

Glossodoris florens Baba, 1949: 53, 143, 144, Text-fig. 60, Pl. 19, fig. 67.

Babaina florens: Odhner, 1968: 867 (cited from Rudman, 1990).

Thorunna florens: Rudman, 1984: 216, 225, 226 (cited from Rudman, 1990); Rudman, 1990: 313-318, figs. 20D, 26F, 26G, 37C, 37D, 39, 40, 41A, 43H; Debelius and Kuiter, 2007: 200; Gosliner et al., 2008: 254.

Material examined. Korea: 2 individuals, Gangwon-do:
Gangneung-si, Anhyeon-dong, 11 Nov 2011; 8 individuals, Goseong-gun, Toseong-myeon, Bongpo-ri, 26 Aug 2012 (KOSPIV00001651-2, KOSPGR0000234416, KOSPGR00 00234421-5).

Diagnosis. Body (length 18-22 mm, width 6-11 mm) elongate, translucent milky white in ground color. Rhinophores lamellate, deep orange in color. Gills seven to eight of simple unipinnate, translucent with deep orange edge (Fig. 1A, B). Mantle widely stretches to cover up the foot. Submarginal band of purple spots along edge of mantle. Two bright yellow striped lines from behind rhinophores to around gills. A yellow spot in front of rhinophores (Fig. 1C, D).

Distribution. Korea, Japan, Thailand, Hong Kong, Indonesia, Australia, Vanuatu.

Remarks. Rudman (1990) indicated that Australian Thorunna florens differed from Japanese and Chinese specimens by dorsal markings on the mantle. Australian specimens have rows of large ovate spots, while Japanese and Chinese spec-
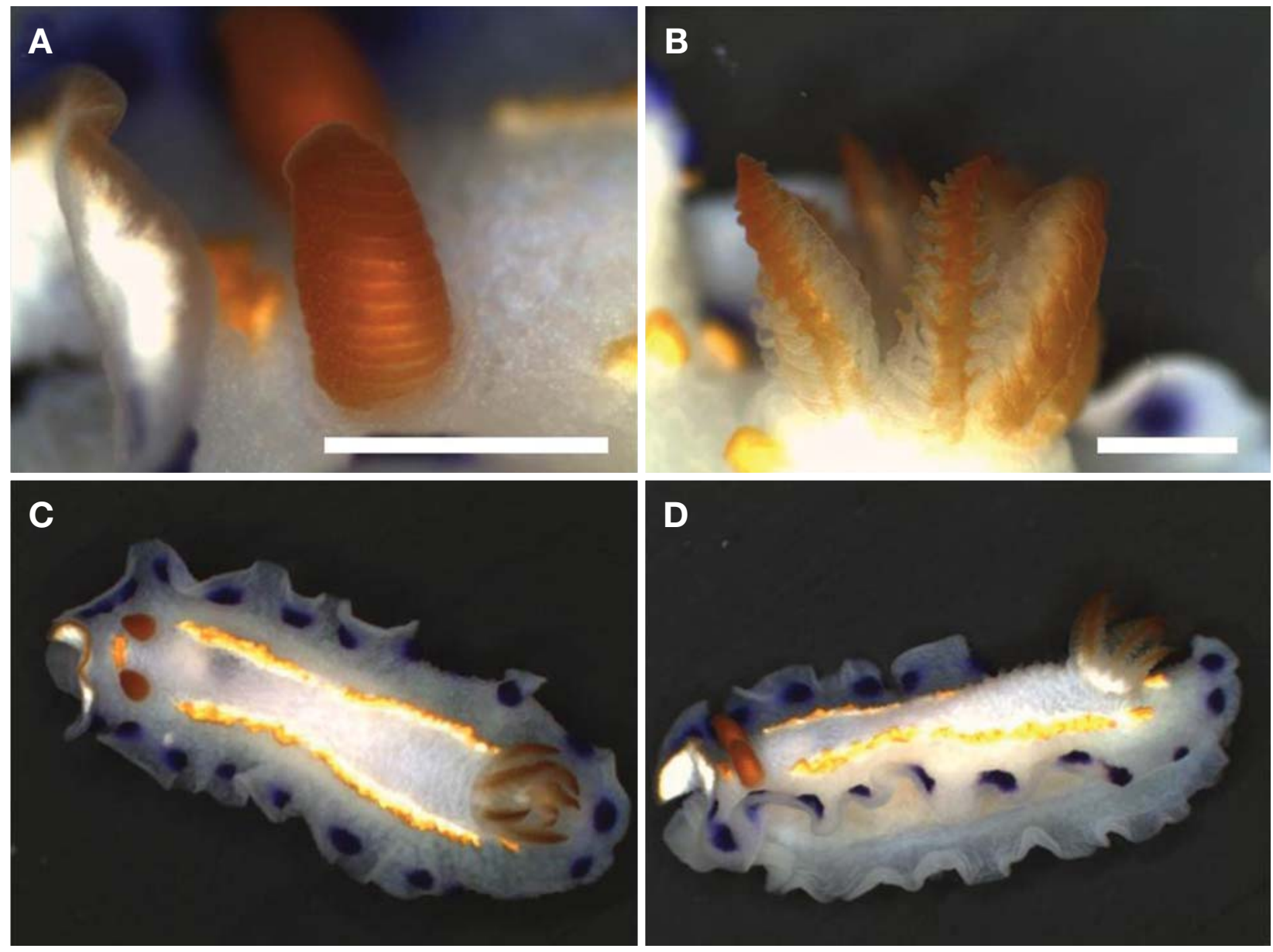

Fig. 1. Thorunna florens (Baba, 1949). A, Rhinophores; B, Gills; C, Dorsal view, preserved specimen (body length, $22 \mathrm{~mm}$ ); D, Lateral view. Scale bars: $A, B=1 \mathrm{~mm}$. 
imens show yellow striped lines. The present specimens are similar to Japanese and Chinese specimens by possessing of the striped line.

Family Discodorididae Bergh, 1891

Genus Diaulula Bergh, 1878

\section{Diaulula sandiegensis (Cooper, 1863) (Fig. 2)}

Doris sandiegensis Cooper, 1863: 58.

Discodoris sandiegensis: Bertsch, 1980: 224 (cited form McDonald, 1983); Mcdonald, 1983: 181, 182.

Diaulula sandiegensis: Baba, 1957: 13, fig. 6; Okutani, 2000: 793, fig. 11; Valdés and Gosliner, 2001: 136-141, figs. 1G, 5A, 24, 25; Behrens and Hermosillo, 2005: 70; Debelius and Kuiter, 2007: 251.

Material examined. Korea: 6 individuals, Gangwon-do: Yangyang-gun, Sonyang-myeon, Susan-ri, 1 March 2011; 2 individuals, Gangneung-si, Anhyeon-dong, 10 May 2011; 2 individuals, Yangyang-gun, Hyeonbuk-myeon, Gisamun-ri, 5 Aug 2012; 1 individual, Gyeongsangbuk-do: Uljin-gun, Wonnam-myeon, Deoksin-ri, 26 Aug 2012 (KOSPIV00001 65225).

Diagnosis. Body (length $35-70 \mathrm{~mm}$, width $23-53 \mathrm{~mm}$ ) ovate and convex. Body white, translucent brown and chocolate brown. Several irregular and various sizes of patches of dark brown rings scattered on dorsum (Fig. 2A, B). Rhinophores elongate with 10 lamellae. Gills with 6 tripinnate brachial leaves. Rhinophores and gills same color as body. Dorsum entirely covered with caryophyllidia about $100 \mu \mathrm{m}$ in length (Fig. 2C), with velvety appearance. The innermost lateral teeth narrow and elongate (Fig. 2D). Mid lateral teeth longer and thicker than inner lateral teeth (Fig. 2E). Outermost lateral teeth falcate with blunt end (Fig. 2F).

Distribution. Korea, Japan, Baja California to Alaska.

Remarks. This species shows a variety of color. Most specimens examined in the previous works are white to pale brown yellow and chocolate brown (Baba, 1957; McDonald, 1983; Okutani, 2000; Valdés and Gosliner, 2001; Debelius and Kuiter, 2007). Specimens examined in the present study showed both translucent white, translucent brown and chocolate brown.

It was suggested that specimens collected from bay areas are normally darker than those from open coastal waters (McDonald, 1983). Specimens collected inside the harbor at Susan-ri showed chocolate brown, with more irregular patches than rings, while specimens obtained outside the harbor of the same area were a bright brown, with more rings than patches (Fig. 2A, B). This may indicate that different habitat conditions produced two variations of body color within this species.
Genus Jorunna Bergh, 1876

Jorunna parva (Baba, 1938) (Fig. 3)

Thordisa parva Baba, 1938: 65, 66, 152, Text-fig. 80, Pl. 24, fig. 90.

Jorunna parva Okutani, 2000: 795; Debelius and Kuiter, 2007: 240, fig. 15; Camacho-García and Gosliner, 2008: 154-156, figs. $1 \mathrm{~F}, 1 \mathrm{G}, 10,11$, Table 2; Gosliner et al., 2008: 189 .

Material examined. Korea: 2 individuals, Jeollanam-do, Sinan-gun, Heuksan-myeon, Gageodo-ri, 9 Oct 2012 (KOS PIV0000165260).

Diagnosis. Body (length 27-40 mm, width 13-21 mm) elongate. Body color dark yellow to brown and lighter around rhinophores and gills. Center of dorsum opaque white (Fig. 3A). Long caryophyllidia, about $80-210 \mu \mathrm{m}$ in length (Fig. 3B), on dorsum show different shape and size. Longer caryophyllidia dark brown, showing dark spots appearance. Rhinophores elongate with 15 lamellae. Gills with 6 bipinnate brachial leaves. Rhinophores and gills dark brown to black. The innermost lateral teeth narrow and elongate (Fig. 3C). Mid lateral teeth little bigger than inner lateral teeth (Fig. 3D). Outermost lateral teeth falcate with blunted end (Fig. 3E).

Distribution. Korea, Japan, Palau, Philippines, Indonesia, Papua New Guinea, western Pacific of Australia, South Africa, Seychells, Tanzania.

Family Dorididae Rafinesque, 1815

Genus Doris Linnaeus, 1758

Doris odhneri (MacFarland, 1966) (Fig. 4)

Austrodoris odhneri MacFarland, 1966: 173-179, Pl. 26, fig. 1, Pl. 29, fig. 14, Pl. 36, figs. 1-19.

Archidoris odhneri: Burn, 1968: 90-92 (cited from McDonald, 1983); McDonald, 1983: 149; Debelius and Kuiter, 2007: 220

Doris odhneri: Behrens and Hermosillo, 2005: 71.

Material examined. Korea: 6 individuals, Gyeongsangbukdo: Uljin-gun, Uljin-eup, Yeonji-ri, 25 Aug 2012; 3 individuals, Gangwon-do: Gangneung-si, Yeongok-myeon, Yeongjin-ri, 19 May 2012; 5 individuals, Gangneung-si, Namhangjin-dong, 9 Sep 2012 (KOSPIV0000165264).

Diagnosis. Body very large and distinctive (length 80-205 $\mathrm{mm}$, width 43-110 mm). Body color white to yellow (Fig. 4A). Rhinophores lamellate. Gills with 7 tripinnate brachial leaves like fluff (Fig. 4B). Rhinophores and gills same color as the body. Dorsum covered with rounded and simple tubercles varying size and shape. Tubercle decrease in size from 

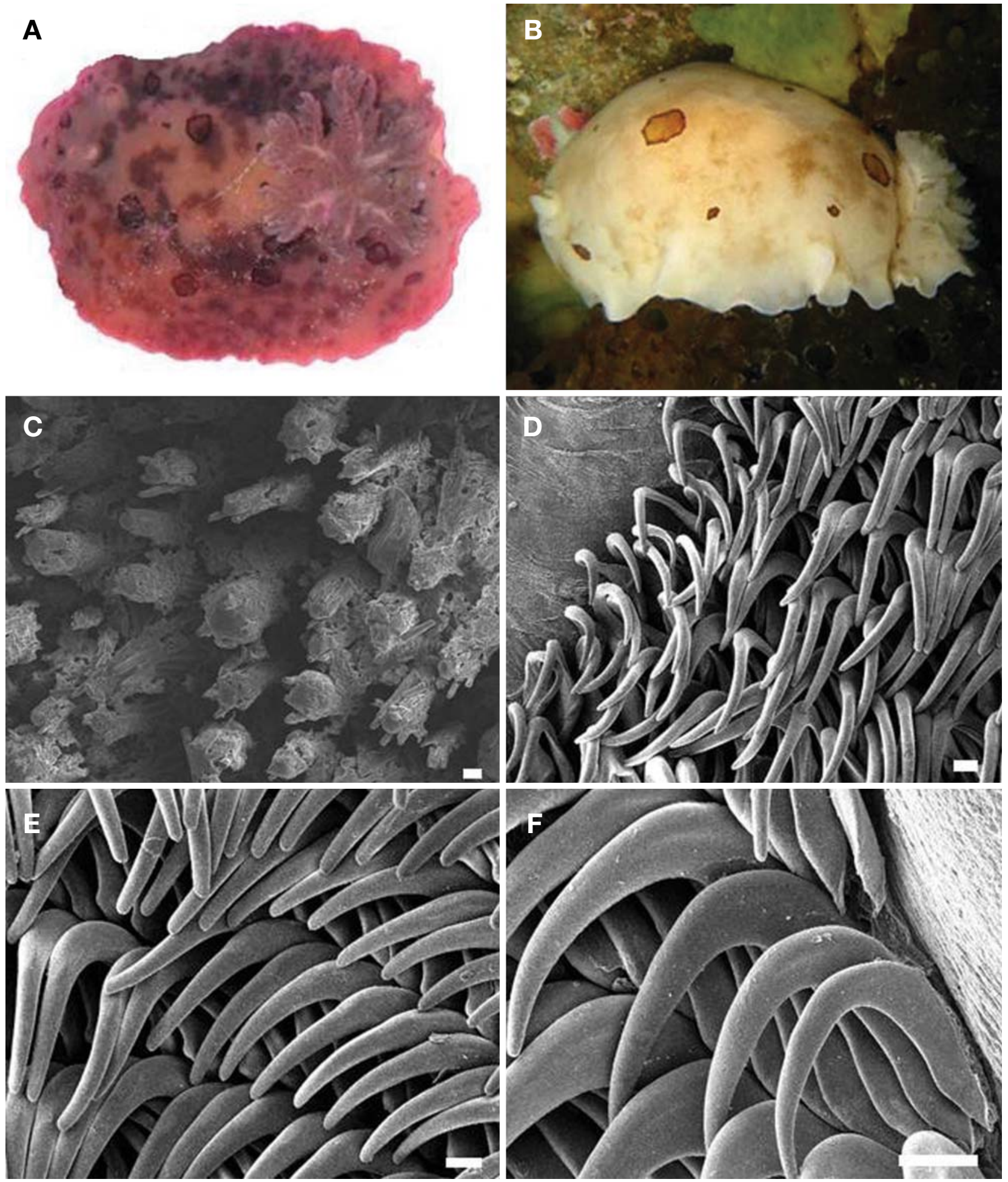

Fig. 2. Diaulula sandiegensis (Cooper, 1863). A, Dorsal view, living animal (body length $65 \mathrm{~mm}$ ); B, Lateral view, living animal (body length $51 \mathrm{~mm}$ ). Scanning electron microscope photographs of radula: C, Caryophillidia on dorsum; D, Central region and inner lateral teeth; E, Mid-lateral teeth; F, Outer lateral teeth. Scale bars: $C-F=50 \mu \mathrm{m}$. 

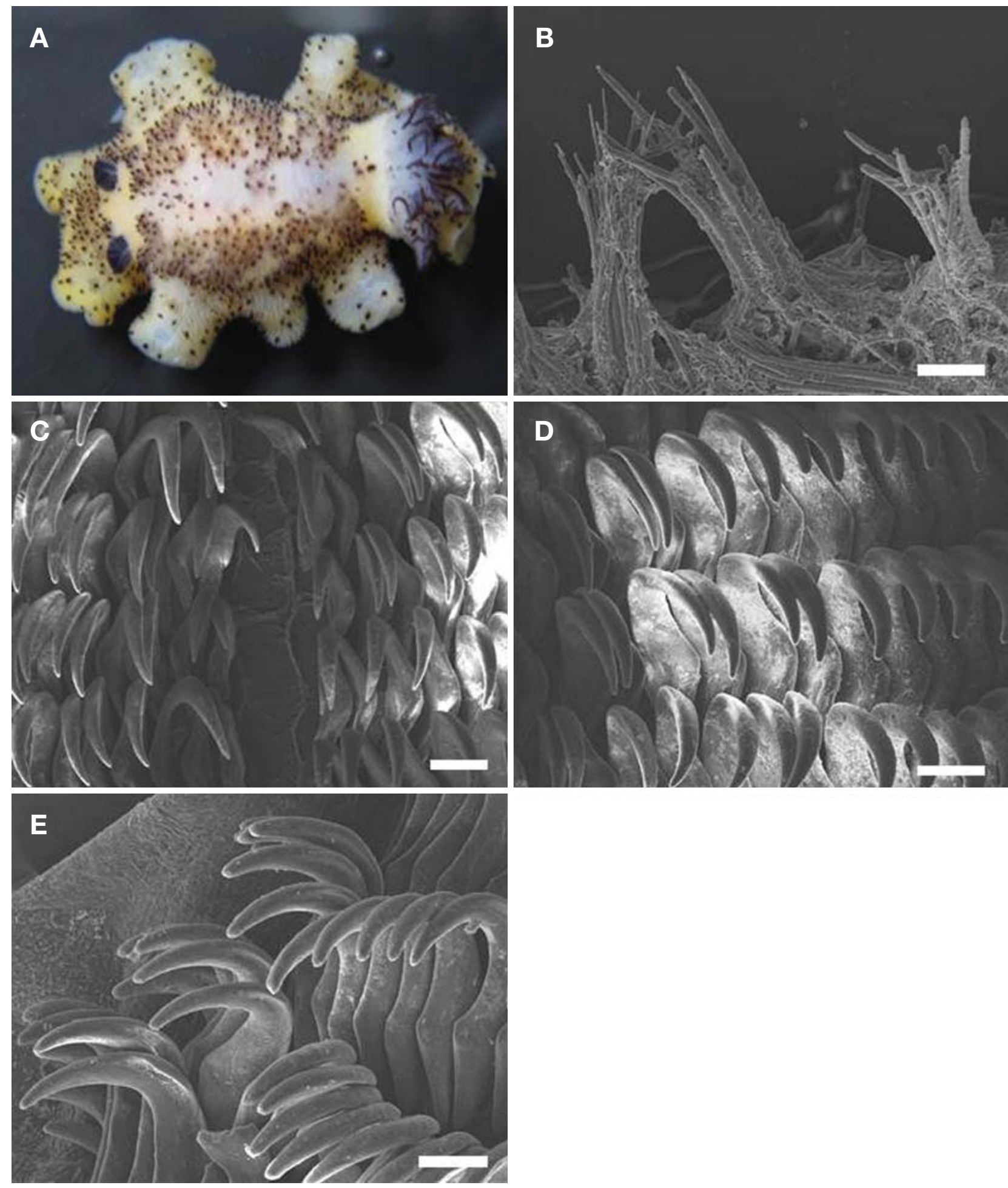

Fig. 3. Jorunna parva (Baba, 1938). A, Dorsal view, preserved specimen (body length, $27 \mathrm{~mm}$ ). Scanning electron microscope photographs of radula: B, Caryophillidia on dorsum; C, Central region and inner lateral teeth; D, Mid-lateral teeth; E, Outer lateral teeth. Scale bars: $B-E=50 \mu \mathrm{m}$. 

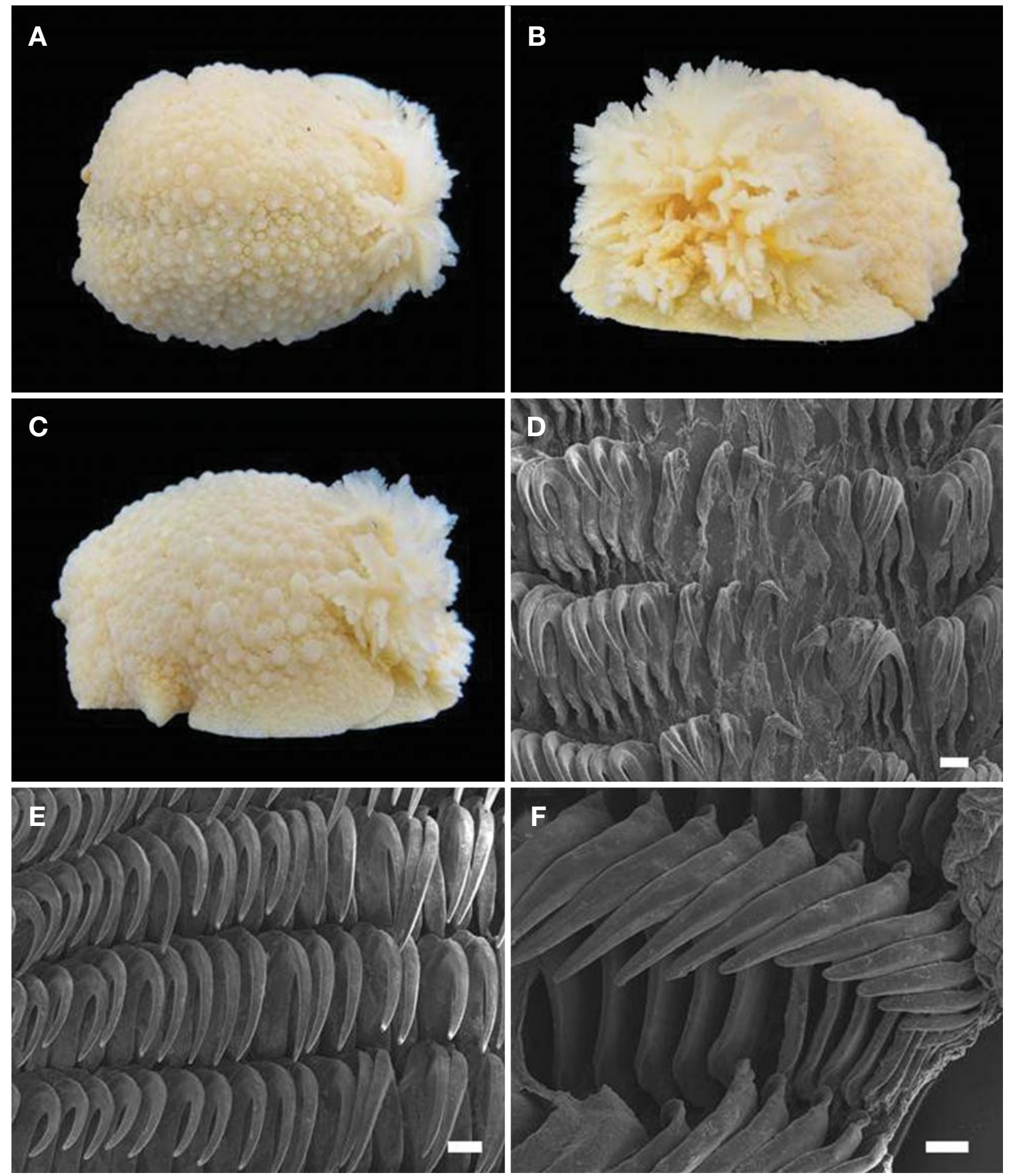

Fig. 4. Doris odhneri (MacFarland, 1966). A, Dorsal view, preserved specimen (body length, $75 \mathrm{~mm}$ ); B, Gills; C, Lateral view. Scanning electron microscope photographs of radula: D, Central region and inner lateral teeth; E, Mid-lateral teeth; F, Outer lateral teeth. Scale bars: $\mathrm{D}-\mathrm{F}=50 \mu \mathrm{m}$. 
top to edge of mantle (Fig. 4C). Innermost lateral teeth short and narrow (Fig. 4D). Mid lateral teeth gradually tapered to tip (Fig. 4E). Outermost lateral teeth falcate (Fig. 4F).

Distribution. Korea, Bering Sea, Alaska, California

Remarks. This species is the biggest nudibranch species in Korea currently known. Body color of the species was reported as white in more materials, and as yellow in rare case (McDonald, 1983; Debelius and Kuiter, 2007). However, most specimens examined here were almost dark yellow, and were white in rare samples.

\section{ACKNOWLEDGMENTS}

This work was supported by a grant from the National Institute of Biological Resources (NIBR), funded by the Ministry of Environment (MOE) of the Republic of Korea (NIBR No. 2012-02-001). We appreciate Gyo-Sang Park for providing photographs.

\section{REFERENCES}

Baba K, 1938. Opisthobranchia of Kii, middle Japan. Journal of the Department of Agriculture, Kyushu Imperial University, 6:1-19.

Baba K, 1949. Opisthobranchia of Sagami Bay, collected by his Majesty the Emperor of Japan. Iwanami Shoten, Tokyo, pp. 1-194.

Baba K, 1957. A revised list of the species of Opisthobranchia from the northern part of Japan, with some additional descriptions. Journal of the Faculty of Science, Hokkaido University, Series 6, Zoology, 13:8-14.

Behrens DW, Hermosillo A, 2005. Eastern Pacific nudibranchs: A guide to the opisthobranchs from Alaska to central America. Sea challengers Natural History Books, Gig harbor, WA, pp. 1-137.

Camacho-García Y, Gosliner TM, 2008. Systematic revision of Jorunna Bergh, 1876 (Nudibranchia: Discodorididae) with a morphological phylogenetic analysis. Journal of Molluscan Studies, 74:143-181.

Choe B, 1992. Illustrated encyclopedia of fauna and flora of
Korea. Vol. 33. Mollusca(II). Ministry of Education, Seoul, pp. 1-860 (in Korean).

Choe BL, Lee JR, 1994. Opisthobranchs (Mollusca: Gastropoda) from Ullung and Dog-do islands, Korea. Korean Journal of Zoology, 37:352-376.

Choi M, 2003. Classification of Doridacea (Gastropoda, Nudibranchia) from sea shores around Je-ju Island. MS thesis, Sungkyunkwan University, Suwon, Korea, p. 100.

Cooper JG, 1863. On new or rare Mollusca inhabiting the coast of California. No. 2. Proceedings of the California Academy of Natural Sciences, 3:56-60.

Debelius H, Kuiter RH, 2007. Nudibranchs of the world. IKANUnterwasserarchiv, Frankfurt, pp. 1-360.

Gosliner TM, Behrens DW, Valdés Á, 2008. Indo-Pacific nudibranchs and sea slugs: a field guide to the world's most diverse fauna. Sea Challengers Natural History Books and California Academy of Sciences, Gig Harbor, WA, pp. 1426.

Lee JR, 1993. Classification of Opisthobranchs from Ullung and Dog-do islands. MS thesis, Sungkyunkwan University, Suwon, Korea, p. 71.

Lee JS, Min DK, 2002. A catalogue of molluscan fauna in Korea. Korean Journal of Malacology, 18:93-217.

MacFarland FM, 1966. Studies of opisthobranchiate mollusks of the Pacific coast of North America. Memoirs of the California Academy of Sciences, 6:1-546.

McDonald GR, 1983. A review of the nudibranchs of the California coast. Malacologia, 24:114-276.

Okutani T, 2000. Marine mollusks in Japan. University of Tokyo Press, Tokyo, pp. 1-1173.

Rudman WB, 1990. The Chromodorididae (Opisthobranchia : Mollusca) of the Indo-West Pacific: further species of Glossodoris, Thorunna and the Chromodoris aureomarginata colour group. Zoological Journal of the Linnean Society, 100:263-326.

Valdés Á, Gosliner TM, 2001. Systematics and phylogeny of the caryophyllidia-bearing dorids (Mollusca, Nudibranchia), with descriptions of a new genus and four new species from Indo-Pacific deep waters. Zoological Journal of the Linnean Society, 133:103-198. 